\title{
P02.41. Yoga for musculoskeletal conditions: a systematic review of intervention protocols
}

\author{
$\mathrm{L} \mathrm{Ward}^{1 *}$, S Stebbings ${ }^{2}, \mathrm{D}$ Cherkin $^{3}, \mathrm{D}$ Baxter $^{1}$ \\ From International Research Congress on Integrative Medicine and Health 2012 \\ Portland, Oregon, USA. 15-18 May 2012
}

\section{Purpose}

To review intervention protocols of yoga for musculoskeletal conditions.

\section{Methods}

Twenty-one databases were electronically searched using database-specific search strings incorporating "yoga", "musculoskeletal", "back pain", "arthritis" and "random". Inclusion criteria were full-text articles of randomised controlled trials, involving yoga as a primary intervention for clinically-diagnosed musculoskeletal conditions in adults. Articles were assessed for methodological quality and risk-of-bias.

\section{Results}

Fifteen articles are included in the systematic review. Articles represent five musculoskeletal conditions, and vary from pilot studies to trials evaluating efficacy and effectiveness of yoga for musculoskeletal conditions. Quality ratings range from 1-8 on the PEDro scale, and 4-17 on the van Tulder scale. Pilot studies tend to show an unclear or high risk of bias, whereas trial studies are predominantly low risk. Heterogeneity in content and reporting of intervention protocols is seen across and within musculoskeletal conditions, as follows. Six styles of yoga were represented, with some protocols based on one style and others an amalgam of different styles. Thirteen interventions were in an outpatient setting (duration 6-24 weeks), and two were in a residential setting (duration 1 week). Hours spent in yoga sessions ranged from 1-56 hours per week and 8-72 hours per intervention. The majority of trials incorporated yoga posture, breathing and relaxation techniques. However, the posture content between trials was difficult to

${ }^{1}$ School of Physiotherapy, University of Otago, Dunedin, New Zealand Full list of author information is available at the end of the article compare at face value due to variations in naming of a posture across different styles of yoga.

\section{Conclusion}

Heterogeneity in the content and reporting of yoga intervention protocols makes comparison of results difficult across studies. To address this challenge of heterogeneity, future research should address which components of a yoga intervention protocol can be standardised, and define a range of variation within which an intervention may still be considered sufficiently homogenous to enable comparison across different research trials.

\section{Author details}

'School of Physiotherapy, University of Otago, Dunedin, New Zealand. ${ }^{2}$ School of Medicine, University of Otago, Dunedin, New Zealand. ${ }^{3}$ Group Health Research Institute, Seattle, USA.

Published: 12 June 2012

\section{doi:10.1186/1472-6882-12-S1-P97}

Cite this article as: Ward et al:: P02.41. Yoga for musculoskeletal conditions: a systematic review of intervention protocols. $B M C$ Complementary and Alternative Medicine 2012 12(Suppl 1):P97.

Submit your next manuscript to BioMed Central and take full advantage of:

- Convenient online submission

- Thorough peer review

- No space constraints or color figure charges

- Immediate publication on acceptance

- Inclusion in PubMed, CAS, Scopus and Google Scholar

- Research which is freely available for redistribution

\section{() Biomed Central}

(c) 2012 Ward et al; licensee BioMed Central Ltd. This is an Open Access article distributed under the terms of the Creative Commons Attribution License (http://creativecommons.org/licenses/by/2.0), which permits unrestricted use, distribution, and reproduction in any medium, provided the original work is properly cited. 